\title{
Pemanfaatan Hasil Perikanan Dalam Bentuk Olahan Daging Ikan Nila Menjadi Nugget Dalam Rangka Diversifikasi Pangan pada Warga RT 07 Desa Kedotan, Kecamatan Sekernan, Kabupaten Muaro Jambi
}

\author{
Indriyani, Silvi Leila Rahmi, Dian Wulansari, Mursyid, Irma Rahmayani \\ Program Studi Teknologi Hasil Pertanian, Fakultas Pertanian, Universitas Jambi \\ Email Corresponding authors: indriyani
}

\begin{abstract}
ABSTRAK
Desa Kedotan yang berada di Kecamatan Sekernan, Kabupaten Muaro Jambi merupakan salah satu desa penghasil ikan nila di Provinsi Jambi. Produksi ikan nila dari daerah ini biasanya hanya dijual dalam bentuk ikan nila segar, dan masih sangat jarang ditemui dalam bentuk olahan. Penganekaragaman produk olahan ikan memiliki keunggulan diantaranya masa simpan yang lama sehingga dapat menjadi alternatif dalam meningkatkan total konsumsi sumber bahan pangan hewani. Selain itu, dapat membantu meningkatkan pendapatan warga desa terutama disaat pandemi corona yang sedang terjadi saat ini untuk dijadikan usaha. Kegiatan pengabdian kepada masyarakat ini bertujuan untuk memberikan pelatihan dan pembinaan kepada masyarakat terkait pemanfaatan potensi daerah yang memiliki nilai jual ekonomis. Adapun bentuk pelatihan yang diberikan adalah pelatihan pengolahan daging ikan nila menjadi produk nugget ikan. Kegiatan pengabdian kepada masyarakat yang dilakukan berlangsung lancar dan baik. Kegiatan ini disambut hangat dan penuh antusias oleh masyarakat terutama ibu-ibu yang berada di Desa Kedotan. Melalui kegiatan ini, diharapkan masyarakat Desa Kedotan tertarik untuk membentuk kelompok usaha produktif berskala UMKM sehingga menambah penghasilan keluarga.
\end{abstract}

Kata Kunci : Ikan nila, Nugget, Pelatihan

\section{PENDAHULUAN}

Ikan nila adalah salah satu jenis ikan air tawar yang banyak ditemukan di berbagai daerah di Indonesia salah satunya di Desa Kedotan, Kabupaten Muaro Jambi, Provinsi Jambi. Masyarakat didaerah ini pada umumnya mencari nafkah dengan melakukan usaha budidaya ikan nila. Ikan nila diketahui memiliki kandungan gizi yang baik bagi kesehatan tubuh dengan dikenal sebagai sumber pangan yang rendah lemak. Dalam 100 gram ikan nila, terkandung sekitar 18,70 gram protein dan hanya 89 kalori. Selain itu, ikan ini juga merupakan sumber vitamin dan mineral yang baik untuk tubuh seperti niacin, vitamin B12, fosfor, selenium, dan kalium (Daftar Komposisi Bahan Makanan, 2004).

Ikan nila hasil budidaya biasanya langsung didistribusikan ke pasar-pasar dalam bentuk ikan segar. Ikan nila segar yang dijual memiliki beberapa kelemahaan diantaranya adalah masa simpannya yang pendek dan harga jualnya yang fluktuatif. Selain itu, pengolahan produk ikan nila saat ini masih terbatas pada bahan olahan lauk pauk saja (ikan goreng, pepes ikan, ikan bakar, ikan gulai, dll). Untuk mengatasi hal tersebut, penganekaragaman produk olahan ikan dapat menjadi solusi untuk memperpanjang masa simpan, meningkatkan total konsumsi sumber bahan pangan hewani serta dapat menambah nilai ekonomis dari produk ikan nila. Salah satu bentuk penganekaragaman produk olahan ikan nila adalah nugget.

Nugget merupakan salah satu hasil olahan yang banyak dikonsumsi dan sangat populer di kalangan masyarakat karena memiliki cita rasa tertentu dan digemari oleh semua golongan umur. Nugget yang biasa dijumpai di pasaran dibuat dari daging ayam, akan tetapi nugget juga 
dapat dibuat dari berbagai jenis bahan pangan lain seperti daging ikan. Pengolahan nugget komersial yang beredar di masyarakat menggunakan filler (bahan pengisi) berupa tepung terigu atau tepung tapioka ataupun tepung lain yang mengandung karbohidrat. Rasa nugget yang dihasilkan terutama berasal dari bumbu-bumbu yang ditambahkan selama proses pembuatan adonan. Bumbu-bumbu tersebut terdiri atas garam, bawang putih, lada dan pala. (Kusumanegara et al., 2012).

Berdasarkan survei lokasi, di Desa Kedotan sampai saat ini masyarakat RT 07 hanya melakukan budidaya perikanan. Hal ini dikarenakan warga belum memiliki pengetahuan dan pemahaman dalam hal pengembangan dan diversifikasi produk. Kegiatan pengembangan dan diversifikasi produk memiliki keuntungan yang lebih, antara lain : (1). Pada produk meningkatkan nilai gizi. (2). Kegiatan diversifikasi produk ini jika dilakukan berkelanjutan bisa menambah pendapatan warga tersebut.

\section{METODE PELAKSANAAN}

Pengetahuan warga mengenai pengembangan dan diversifikasi ikan nila baik dari segi jenis maupun teknik pengolahan sangat minim. Oleh karena itu, solusi yang ditawarkan adalah melakukan sosialisasi dan demonstrasi kepada warga RT 07 Desa Kedotan, Kabupaten Muaro Jambi, Provinsi Jambi. Materi pelatihan berupa penyuluhan (ceramah) dan praktek (demonstrasi) meliputi:

1. Sosialisasi tentang berbagai macam pengembangan dan diversifikasi produk berbasis ikan

2. Teknik pengolahan nugget ikan (proses dan peralatan)

Kegiatan-kegiatan yang akan dilakukan berdasarkan solusi yang ditawarkan adalah:

1. Pelatihan kepada warga RT 07.

2. Monitoring dan evaluasi dari berbagai tahap kegiatan yang dilakukan.

Adapun rencana kegiatan yang telah disepakati bersama yaitu melakukan bimbingan, penyuluhan dan demonstrasi cara memproduksi nugget ikan.

\section{HASIL DAN PEMBAHASAN}

Kegiatan pengabdian kepada masyarakat dilaksanakan pada tanggal 15 agustus 2020 di kediaman Kepala Dusun Mudo. Adapun bentuk kegiatan yang diberikan pada kegiatan PPM ini terdiri dari 3 tahapan, yaitu tahapan penyuluhan dengan presentasi oleh Ketua Tim Pengabdian, tahapan demonstrasi oleh anggota tim pengabdian beserta mahasiswa yang diikutsertakan, serta tahapan diskusi yang dilakukan antara peserta dan semua anggota tim pengabdian. Setiap peserta yang hadir mendapatkan modul teknologi pengolahan nugget ikan nila yang telah disiapkan oleh tim pengabdian kepada masyarakat.

Kegiatan diawali dengan penyuluhan (ceramah) mengenai manfaat pengolahan daging ikan nila beberapa produk di khususkan dalam bentuk produk nugget. Dilakukan demonstrasi tentang cara pembuatan produk nugget dengan melibatkan para peserta. Seiring dengan melakukan pembuatan produk peserta diberikan kesempatan untuk bertanya hal-hal yang belum dimengerti tentang pembuatan produk tersebut ataupun pertanyaan - pertanyaan berhubungan dengan peningkatan usaha.

Kegiatan pengabdian kepada masyarakat yang dilakukan berlangsung lancar dan baik. Kegiatan ini disambut hangat dan penuh antusias oleh masyarakat terutama ibu-ibu yang berada di Desa Kedotan. Hal ini terlihat dari keaktifan peserta berdiskusi selama kegiatan ini berlangsung. Selain itu, Kepala Dusun (Kadus) Dusun Mudo, Samsul Komar, juga menyambut 
positif kegiatan ini, hal ini terkait masih kurangnya pengolahan potensi ikan nila yang ada di Desa Kedotan. Melalui kegiatan ini, diharapkan masyarakat Desa Kedotan terutama ibu-ibu tertarik untuk membentuk kelompok usaha produktif berskala UMKM sehingga menambah penghasilan keluarga.

Pemanfaatan daging nila menjadi produk olahan berupa nugget menarik perhatian para peserta kegiatan. Hal ini dikarenakan banyak peserta yang belum tahu bagaimana mengolah daging ikan nila menjadi produk-produk yang memiliki nilai jual. Selama ini, ibu-ibu warga RT07 baru melaksanakan olahan daging ayam menjadi nugget. Kurang pengetahuan tentang penglahan ikan yang dikhawatirkan pada bau yang amis, membuat warga tidak mencoba mengolah daging ikan nila tersebut. Dengan kegiatan pengabdian ini, peserta sangat senang karena mendapat pengetahuan baru dan setelah mencoba langsung produk nugget daging ikan nila tersebut mereka semakin tertarik karena rasanya enak dan sehat.

Ketertarikan peserta juga ditunjukkan oleh beberapa peserta yang bertanya lebih dalam mengenai perbandingan bahan yang digunakan jika diolah dalam jumlah besar, tahapan proses hingga masa simpan nugget ikan nila. Peserta juga antusias ikut terlibat langsung dalam praktek demonstrasi pengolahannya. Pada akhir kegiatan, peserta menyampaikan keinginannya untuk memulai membuat produk nugget daging ikan nila yang bertujuan nantinya menjadi usaha, sehingga diharapkan dapat menambah penghasilan serta menambah variasi makanan.

Kegiatan pengabdian ini belum menjelaskan secara detail mengenai kelayakan ekonomis usaha produk olahan nugget ikan nila dan teknik pemasaran yang dapat dilakukan untuk produk tersebut. Hal ini menjadi masukan bagi tim pelaksana pengabdian kepada masyarakat untuk dapat merencanakan kegiatan tersebut di masa yang akan datang.

\section{KESIMPULAN DAN SARAN}

Kegiatan pengabdian kepada masyarakat ini bertujuan untuk memberikan pelatihan dan pembinaan kepada masyarakat terkait pemanfaatan potensi daerah yang memiliki nilai jual ekonomis. Adapun bentuk pelatihan yang diberikan adalah pelatihan pengolahan daging ikan nila menjadi produk nugget ikan. Berdasarkan hasil kegiatan yang telah dilakukan, disarankan untuk melanjutkan kegiatan pengabdian ini berupa pelatihan mendisign kemasan, triktrik pemasaran kekinian serta perhitungan ekonomi.

\section{DAFTAR PUSTAKA}

Daftar Komposisi Bahan Makanan. 2004. Jakarta: LIPI.

Kusumanegara, A.I, Jambahri, dan Erwanto, Y. Kualitas Fisik, Sensoris Dan Kadar Kolesterol Nugget Ampela Dengan Imbangan Filler Tepung Mocaf Yang Berbeda. Buletin Peternakan Vol. 36(1): 19-24, 2012. 